\title{
Mistérios do Superendividamento do Consumidor
}

Segundo levantamento do Serasa Experian, no primeiro semestre de 2019, a inadimplência atingiu 63 milhões de consumidores brasileiros, marcando um recorde histórico ${ }^{1}$.

Os múltiplos canais de informação na atualidade, especialmente o audiovisual, veiculando videoaulas de educação financeira, vieram pra ficar, e estão cada vez mais populares, prestando um bom serviço, inclusive sem custo aos usuários, a exemplo do youtube o mais popular deles,.

Mesmo com esta democratização de informações, os números mostram que há muito que aprender sobre a base da economia doméstica, cuja conta, aparentemente simples, é ensinada a todos, num ditado popular: 'não gaste mais do que ganhe!'; ainda assim, no final esta equação não fecha.

Excluindo desta análise, o cenário econômico, ou medidas macroeconômicas de governo que afetam o (des)emprego; o consumismo, possivelmente, é uma das causas, destas dificuldades, e se alimenta no mais das vezes, de necessidades artificiais; criadas por uma espécie de engenharia social, que infiltra em nossas mentes, uma 'vontade' insaciável de consumir.

Uma vez impregnadas em nossa mente estas necessidades artificiais, advém a compulsão sem fim, às vezes variando quanto ao objeto. E assim, em certos momentos sofremos por não ter o carro do ano; uma joia, ou o último smartphone lançado; nem sempre atentos à necessidade real e que não estoure o cartão de crédito ou o cheque especial.

Em 1818, já na fase da revolução industrial, porém, ainda sem uma infinidade de produtos no mercado, o filósofo Schopenhauer já intuía que em algum momento, o querer, que até então servia a inteligência, acabaria sendo suprimido: A obra última da inteligência será a supressão do querer, a cujos fins havia servido até então. ${ }^{2}$

Assim, nossa vontade, que a princípio deve se assentar na inteligência, na razão, nos bons propósitos, se enfraquece, sendo substituída pela vontade do mercado, do mundo empresarial; que num primeiro momento vende sonhos, mas quiçá à custa de algum pesadelo.

\footnotetext{
${ }^{1}$ https://www.serasaexperian.com.br/sala-de-imprensa/inadimplencia-atinge-63-milhoes-de-consumidores-emmarco-e-bate-recorde-historico-revela-serasa-experian

${ }^{2}$ Schopenhauer. O Mundo como Vontade e como Representação II, cap. 48)
} 
O pensador polonês Zygmunt Bauman, falecido em 2017, se debruçou com afinco sobre o tema consumismo, em sua obra Vida para Consumo - A transformação das pessoas em mercadoria (2008).

Para ele, a submissão das pessoas às técnicas do marketing, ao consumismo, ocorre com o concurso do consumidor, desejoso de atrair a atenção e aprovação, no jogo da sociabilidade; que é absorvido com tal força, que deixamos de enxergar a linha divisória entre o produto e a pessoa - pois os produtos que são encorajadas a colocar no mercado, promover e vender são elas mesmas ${ }^{3}$. Numa sociedade de consumidores, tornar-se uma mercadoria desejável e desejada é a matéria de que são feitos os sonhos e os contos de fada $^{4}$.

Atermo-nos às coisas simples da vida, pode ser uma fórmula mágica do bem viver. Não com tal desapego, que certo dia lemos de um autor, e nos escusamos por não recordar a fonte: 'adoro ir ao mercado pra ver a quantidade de coisas que não preciso"; mas com equilíbrio e planejamento, já que, no sistema capitalista que vivemos, não é possível viver ignorando suas regras.

Ricardo Calil Fonseca - advogado em Itaberaí - GO desde 1992, com atuação nos ramos trabalhista, cível, penal e previdenciário. Presidente da Subseção da OAB/GO de Itaberaí (2016/2018); e atual Presidente da Academia de Letras e Artes de Itaberaí (AILA).

\footnotetext{
${ }^{3}$ BAUMAN, Zygmunt Vida para Consumo - A transformação das pessoas em mercadoria (2008), pág. $12,13$.

${ }^{4}$ BAUMAN, Zygmunt. Obra citada, pág. 22.
} 